\title{
KANSALAISTEN POLIITTINEN \\ OSALlistUminen JA TIETÄMYS SUOMESSA
}

\author{
بुy \\ Mitä parempi poliittinen tietämys, sitä aktiivisemmin suomalaiset \\ osallistuvat politiikkaan. Tietämys ei kuitenkaan takaa oikeita valintoja, \\ sillä politiikassa ei ole kyse vain vaihtoehtojen oikeellisuudesta vaan \\ henkilökohtaisesta kokemuksesta.
}

TÄSSÄ ARTIKKELISSA tarkastellaan politiikkaan liittyvän tietämyksen roolia poliittisen osallistumisen selittäjänä Suomessa. Kysymyksen taustalla on edustuksellisen demokratian olemassaolon perusta ja oikeutus: kansalaisten mahdollisuus ja omaehtoinen halukkuus osallistua yhteiskunnalliseen päätöksentekoon. Lisäksi edustuksellisen demokratian toimintalogiikka asettaa kansalaisille pätevyysvaatimuksen: osallistuminen ei voi perustua täydelliselle poliittiselle tietämättömyydelle, vaan mielipiteenilmaisujen oletetaan olevan yhteydessä politiikan tosiasioihin ja tapahtumiin - vaikka kansalaiset tosiasioita eri tavoilla tulkitsevatkin. ${ }^{1}$

Analyysin tärkein poliittista osallistumista selittävä muuttuja onkin politiikkatietämys. Sillä tarkoitetaan politiikkaa koskevien tosiasioiden hallintaa (Milner 2002, 53; ks. myös Rapeli 2010, 23-28). Teoreettisesti politiikkatietämys ja poliittinen osallistuminen kytkeytyvät toisiinsa demokratiateoriassa käytävän kansalaiskompetenssin käsitteistön ja keskustelun kautta. Artikkelissa arvioidaan analyysin tuloksia tämän keskustelun kautta.
Poliittisen osallistumisen selittäminen politiikkatietämyksellä ei ole kausaalisesti ongelmatonta. Sen todentaminen, kumpi johtaa kumpaan, on tuskin edes analyyttisesti mielenkiintoista. Suhdetta lähestytäänkin tutkimuksessa molemminpuolisena vastavuoroisuutena, ja tarkoitus on analysoida osallistumista ja tietoa kahden keskinäisriippuvan muuttujan yhteytenä pyrkimättä selittämään sitä kausaalisuhteena.

\section{PERINTEINEN JA EI-PERINTEINEN POLIITTINEN OSALLISTUMINEN}

Edustuksellisessa demokratiassa äänestäminen on näkyvin ja tavanomaisin - muttei ainoa - kansalaisosallistumisen muoto. Kansalaiset voivat esimerkiksi kirjoittaa mielipiteensä valitsemansa median yleisönosastoon, nimensä vetoomukseen tai ottaa yhteyttä poliittiseen päätöksentekijään. Tämänkaltaisia vaikuttamistapoja kutsutaan perinteisiksi, sovinnaisiksi tai konventionaalisiksi osallistumismuodoiksi. Niille yhteistä on niiden liittyminen institutionalisoituihin poliittisiin prosesseihin (Marsh \& Kaase 1979, 84). Ei-perinteiset osallistumismuodot taas eivät ole in- 
stitutionalisoituja, vaan luonteeltaan epäsäännöllisiä ja vaikeammin ennakoitavia. Niitä ovat esimerkiksi harkitut ostopäätökset, boikotit, kansalaistottelemattomuus sekä mielenosoitukset.

Perinteisten osallistumisen muotojen pysyvyys on tärkeä osa demokraattista yhteiskuntaa ja siksi niiden toteutumista seurataankin ahkerasti. Äänestysaktiivisuuden muutokset ovat aiheuttaneet paljon uutisointia ja keskustelua myös Suomessa. Demokratian legitimiteetin katsotaan usein kulminoituvan juuri äänestämiseen. Äänestäminen voidaan nähdä tapahtumana, jossa kansalaiset antavat tukensa poliittiselle järjestelmälle (Topf 1995, 27). Sen sijaan ei-perinteisten osallistumisen muotojen seuranta on epäsäännöllisempää jo pelkästään niiden luonteen takia (Bengtsson \& Grönlund 2005, 149). Vaikka näiden poliittisen vaikuttamisen muotojen suosion kasvu onkin Suomessa viime vuosikymmeninä ollut varsin maltillista, on potentiaali tämänkaltaiseen osallitumiseen kasvanut samana aikana sitäkin enemmän (Bengtsson \& Grönlund 2005, 149).

Myös tämän artikkelin analyysi perustuu osallistumismuotojen jaottelulle perinteisiin ja ei-perinteisiin osallistumismuotoihin ${ }^{2}$. Tuloksia peilataan normatiivisen demokratiateorian keskusteluun poliittisen osallistumisen ja kansalaispätevyyden välisestä suhteesta. Kysymykseksi muodostuu tällöin, ovatko aktiivisimmin osallistuvat yksilöt myös poliittisesti tietävimpiä. Empiirisesti kysymystä tutkitaan tarkastelemalla, kuinka suuri merkitys faktatietämyksellä on poliittisen osallistumisen selittäänä. Normatiiviselta kannalta samalla pohditaan, tulisiko näin olla.

\section{POLIITTINEN OSALLISTUMINEN JA KANSALAISKOMPETENSSI}

Edustuksellisen demokratian toimivuus perustuu kansalaisten vapaaehtoiselle osallistumiselle ja siksi poliittinen toiminta myös edellyttää kansalaisilta tiettyjä asioita. Osallistumistaidoiltaan pätevän kansalaisen kuvailu ei kuitenkaan ole yksinkertainen tehtävä. Bernard Berelson on laatinut ehkä merkittävimmän kansalaiseen liitettävien odotuksien listoista, joka kansalaisominaisuuksien kuvauksena on kattava ja yksityiskohtainen. Vaikka Berelson liikkuu analyysissään koko äänestäjäkunnan tasolla, hänen mai- nitsemansa ominaisuudet ovat tyypiltään yksilöä kuvaavia. Demokratiaan sopii Berelsonin mukaan luonteeltaan sellainen ihminen, joka kykenee kantamaan moraalisen vastuun tekemistään päätöksistä sekä käsittelemään oman pettymyksensä vastapuolen kannan voittaessa. Kompetentti kansalainen on myös itsevarma, terveen kriittinen auktoriteetteja kohtaan, eikä turhan alistuva tai yltiöpäisen aggressiivinen. Demokratian toimivuutta eivät kuitenkaan takaa vain sopivat luonteenpiirteet. Lisäksi edellytetään, että äänestäjäkunta toimii yksilön sijaan yhteisön parhaaksi, käy keskustelua politiikasta, kykenee havainnoimaan politiikan reaaliteetteja objektiivisesti, omaa tietoa politiikasta sekä sen tapahtumista ja lopulta osallistuu poliittisesti. (Berelson 1952.)

Tämä kansalaiskompetenssin tiedollinen ulottuvuus on keskeinen juuri poliittisen osallitumisen kannalta. Berelson ym. $(1954,308)$ argumentoivat, että demokratiaa ajatellen ihannekansalaisella tulisi olla hallussaan tietoa itse politiikasta sekä päätettävistä asioista ja ajankohtaisista tapahtumista. Russell Neumanin $(1986,189)$ mukaan kansalaisen tulee ymmärtää, mitä poliittinen hallinto (government) tekee, miten se toimii ja minkälaiselle arvopohjalle sen toiminta perustuu. Robert Weissberg (1974, 71) puolestaan huomauttaa, että kansalaisen (etenkin äänestäjän) on tiedettävä poliittisen järjestelmän perusasiat, poliittisten instituutioiden väliset suhteet ja poliittisen vastuun sijainti.

Nämä demokratiateoreetikkojen kannanotot perustuvat ajatukselle, jonka mukaan tieto vaikuttaa osallistumiseen. Osallistumisen, esimerkiksi äänestämisen, ei normatiivisessa demokratiateoriassa oleteta olevan sattumanvaraista, vaan perustuvan vähimmilläänkin alkeelliselle ymmärrykselle poliittisesta järjestelmästä (Weissberg 1974; ks. myös Rapeli 2010, 86-87).

\section{AINEISTO JA MUUTTUJAT}

Aineistona analyysissä käytetään Eduskuntavaalitutkimus 2011 -kyselyaineistoa (FSD2653)33. Analyysissä on kaksi selitettävää muuttujaa: perinteinen ja ei-perinteinen poliittinen osallistuminen. Tutkimuksessa mitattiin sekä osallistumista että osallistumispotentiaalia. Tässä analyysissä tarkastellaan pääasi- 
assa todellista osallistumista osallistumispotentiaalin sijaan. Muuttujien kysymystekstit ja koodaus on raportoitu liitteessä.

Perinteisiksi on luokiteltu seuraavat kuusi osallistumismuotoa: Äänestäminen viimeisimmissä eduskuntavaaleissa (2011)4; kirjoittaminen yleisönosastoon; yhteydenotto poliittisiin päätöksentekijöihin jossakin tärkeässä asiassa; nimen kirjoittaminen vetoomuksiin tai nimenkeräyksiin; osallistuminen poliittisen puolueen toimintaan; osallistuminen muun järjestön toimintaan.

Ei-perinteisiksi on luokiteltu seuraavat seitsemän osallistumismuotoa: ostopäätösten teko siten, että kulutustavat edistävät luonnonsuojelua; ostopäätösten teko siten, että kulutustavat vaikuttavat yhteiskunnallisiin tai poliittisiin asioihin; osallistuminen boikottiin, maksu- tai ostolakkoon; osallistuminen rauhanomaisiin mielenosoituksiin; kansalaistottelemattomuuden osoittaminen osallistumalla väkivallattomaan laittomaan toimintaan; osallistuminen sellaisiin mielenosoituksiin, joissa aiemmin on ilmennyt väkivaltaa; väkivallan käyttäminen poliittisten päämäärien saavuttamiseksi.

Keskeisin poliittista osallistumista selittävä muuttuja on politiikkatietämys. Vuoden 2011 kyselyssä kysyttiin seuraavat viisi yleistä poliittista tietämystä mittaavaa kysymystä ( ${ }^{*}=$ oikea vastaus $)$ :

1. Kuka seuraavista oli vuonna 2010 Suomen hallituksen ulkoministeri? (Erkki Tuomioja; Astrid Thors; Olli Rehn; Alexander Stubb*)

2. Mikä seuraavista on paikkamäärältään juuri valitun eduskunnan neljänneksi suurin puolue? (Kansallinen Kokoomus; Suomen Keskusta*; Suomen Sosialidemokraattinen Puolue; Perussuomalaiset)

3. Ketkä saavat äänestää Suomen eduskuntavaaleissa? (kaikki 18 vuotta täyttäneet Suomessa asuvat Suomen kansalaiset; kaikki 18 vuotta täyttäneet Suomen kansalaiset asuinmaasta riippumatta*; suomalaisten lisäksi Suomessa asuvat 18 vuotta täyttäneet Euroopan unionin jäsenmaiden kansalaiset; kaikki ne 18 vuotta täyttäneet Suomen kansalaiset, jotka eivät oikeuden päätöksellä ole menettäneet kansalaisluottamustaan esim. vankeusrangaistuksen vuoksi)
4. Mitä mielestänne tarkoitetaan parlamentaarisella hallitusmuodolla? (kansanvaltaa; sitä että eduskunta nauttii hallituksen luottamusta; sitä että hallitus nauttii eduskunnan luottamusta*; sitä että hallitus nauttii presidentin luottamusta)

5. Millä nimellä tunnetaan Euroopan unionin (EU) vuoden 2009 lopussa voimaan astunut perussopimus? (Geneven sopimus; Schengenin sopimus; Lissabonin sopimus*; Maastrichtin sopimus)

Jokaisesta oikeasta vastauksesta on koodattu 1 piste, joten yksinkertainen, additiivinen summamuuttuja voi saada kokonaisluvun arvojen 0 ja 5 välillä. Summamuuttuja on uudelleen koodattu arvojen 0 ja 1 välille. Tietämyksen lisäksi kontrollimuuttujina käytetään koulutustasoa, ikää, sukupuolta, tulotasoa, poliittista kiinnostusta, itsearvioitua sijaintia vasemmisto-oikeisto-ulottuvuudella sekä luottamusta eduskuntaa kohtaan. Muuttujien koodaus on raportoitu liitteessä.

Kansalaisten luottamus poliittisiin instituutioihin kertoo, missä määrin he katsovat instituutioiden täyttävän niille asetetut normatiiviset odotukset (esim. Warren 1999, 349-350; ks. myös Grönlund \& Setälä 2007, 401-406). Näin ajateltuna luottamuksen poliittisiin instituutioihin voidaan olettaa olevan yhteydessä siihen, missä määrin kansalaiset ovat halukkaita osallistumaan poliittisesti. Vaikka käytettävä aineisto mahdollistaisi luottamuksen operationalisoinnin useiden eri poliittisten toimijoiden kohdalla, käytetään tässä analyysissä ainoastaan luottamusta eduskuntaan, sillä sen katsotaan edustavan lakiasäätävänä tahona parlamentaarisen poliittisen järjelmän tärkeintä instituutiota. Eduskunta liittyy lisäksi empiirisesti käytettävään aineistoon, koska analyysissä mitataan nimenomaan eduskuntavaaleissa äänestämistä.

\section{ANALYYSI}

Taulukossa 1 on esitetty eri osallistumismuotojen yleisyys Suomessa prosenttiosuuksina eri vastausvaihtoehdoista. Vastaamatta jättäneiden osuudet on jätetty huomiotta. Osallistumismuodot ovat laskevassa järjestyksessä sen mukaan, kuinka suuri osuus 
Taulukko 1. Osallistumismuotojen yleisyys Suomessa 2011(\%) ( $n=1311$ ).

\begin{tabular}{|l|r|r|r|}
\hline Osallistumismuoto & $\begin{array}{c}\text { Tehnyt viimeisten } \\
\text { 4 vuoden aikana }\end{array}$ & $\begin{array}{c}\text { Saattaisi } \\
\text { tehdä }\end{array}$ & $\begin{array}{c}\text { Ei tekisi missään } \\
\text { tapauksessa }\end{array}$ \\
\hline Edistää luonnonsuojelua ostopäätöksillä & 62,0 & 28,9 & 7,9 \\
\hline Allekirjoittaa vetoomuksen/ nimenkeräyksen & 45,3 & 41,5 & 12,5 \\
\hline Osallistua muuhun järjestötoimintaan & 37,6 & 42,0 & 19,6 \\
\hline Vaikuttaa yhteiskuntaan ostopäätöksillä & 35,8 & 44,9 & 16,4 \\
\hline Ottaa yhteyttä päätöksentekijään & 19,0 & 58,9 & 21,8 \\
\hline Osallistua boikottiin, maksu- tai ostolakkoon & 18,0 & 48,4 & 31,6 \\
\hline Kirjoittaa yleisönosastoon & 14,7 & 54,2 & 30,6 \\
\hline Osallistua puoluetoimintaan & 10,1 & 39,0 & 49,8 \\
\hline Osallistua rauhanomaisiin mielenosoituksiin & 8,9 & 43,8 & 46,4 \\
\hline Osoittaa kansalaistottelemattomuutta laittomasti, mutta väkivallatta & 2,7 & 18,6 & 78,3 \\
\hline Osallistua mielenosoitukseen, jossa aiemmin väkivaltaa & 0,2 & 6,2 & 93,2 \\
\hline Käyttää väkivaltaa poliittisiin päämääriin & 0 & 1,8 & 98,1 \\
\hline
\end{tabular}

Eduskuntavaalitutkimus 2011

vastaajista oli osallistunut kysytyllä tavalla viimeisten neljän vuoden aikana.

Väkivaltaista käyttäytymistä lukuun ottamatta kaikki vaihtoehdot kuuluivat vastaajien käyttämiin osallistumistapoihin. Suurimmalla osalla osallistuminen rajoittuu kuitenkin äänestämiseen sekä luonnonsuojelun edistämiseen kulutustottumuksien avulla. Konventionaalisista osallistumistavoista suosituin on nimen kirjoittaminen vetoomukseen. Melkein 90 prosenttia vastaajista oli tehnyt näin tai oli valmis siihen. Muuhun järjestötoimintaan osallistuminen oli puoluetoimintaa suositumpaa. Vain joka kymmenes oli osallistunut puoluetoimintaan viimeisen neljän vuoden aikana ja jopa puolet vastaajista piti sitä täysin poissuljettuna.

Epäkonventionaalisten osallistumistapojen osalta havaitaan, että kulutuskäyttäytymisellä vaikuttaminen on suomalaisille varsin tuttua. Luontoystävällisemmän tuotteen valitsemisen lisäksi myös ostopäätöksien kautta yhteiskuntaan vaikuttaminen oli melko yleistä. Selvä vähemmistö kyselyyn vastanneista oli lähimenneisyydessä osallistunut mielenosoituksiin, mutta huomionarvoista on, että yli puolet näki sen mahdollisena vaihtoehtona. Asenne kovempia keinoja kohtaan oli selvän torjuva.

Taulukossa 2 on esitetty yhteiskunnallisen osallistumisen aktiivisuus eri vastaajaryhmissä. Analyysi sisältää kuusi perinteisen ja ei-perinteisen osallistumi- sen muotoa, joten taulukon ryhmäkeskiarvot voivat vaihdella välillä 0-6. Ryhmäkeskiarvon jälkeen suluissa on raportoitu keskipoikkeamat. Jokaisen selittävän muuttujan sekä selitettävän osallistumistavan kohdalla on ilmoitettu Etan neliö -arvo, joka kuvaa muuttujien välisen riippuvuuden voimakkuutta. Esimerkiksi ensimmäisessä kohdassa sukupuoli selittää nolla prosenttia perinteisen osallistumisen määrän vaihtelusta ja 2,2 prosentia ei-perinteisen osallistumisen tapojen lukumäärän vaihtelusta. Tähdet indikoivat tilastollista merkitsevyyttä $\left({ }^{* * *}=<0.1 \%\right.$; $\left.^{* *}=<1 \%{ }^{*}=<5 \%\right)$.

Perinteisen osallistumisen osalta selvästi merkittävin vaihtelun selittäjä on kiinnostus politiikkaa kohtaan, joka selittää peräti 23 prosenttia osallistumisaktiivisuudesta. Erittäin kiinnostuneet kansalaiset ottavat keskimäärin osaa politiikkaan yli kolmella perinteiseksi luokitellulla tavalla ja aktiivisuus laskee kiinnostuksen laskun mukana. Ei lainkaan politiikasta välittävät osallistuivat keskimäärin enää alle yhdellä tavalla. Kiinnostuksella oli samansuuntainen vaikutus myös ei-perinteisten osallistumismuotojen kohdalla, mutta vaihtelu oli lievempää. Kiinnostuneimmat osallistuivat keskimäärin 1,68 tavalla ja vähiten asiasta kiinnostuneet keskimäärin 0,73 tavalla.

Koulutuksen ja poliittisen tietämyksen merkitystä on syytä korostaa. Perinteisen poliittisen osallistumisen osalta enintään peruskoulun suorittaneet osallistuivat huomattavasti vähemmän kuin pidem- 


\begin{tabular}{|c|c|c|}
\hline & $\begin{array}{c}\text { Perinteinen } \\
\text { osallistuminen }\end{array}$ & $\begin{array}{l}\text { Ei-perinteinen } \\
\text { osallistuminen }\end{array}$ \\
\hline \multicolumn{3}{|l|}{ Sukupuoli } \\
\hline Mies & $1,97(1,48)$ & $1,1(1,15)$ \\
\hline Nainen & $1,99(1,44)$ & $1,45(1,22)$ \\
\hline $\mathrm{Eta}^{2}$ & .000 & $.022^{* * *}$ \\
\hline \multicolumn{3}{|l|}{ Koulutus } \\
\hline Enint. peruskoulu & $1,43(1,34)$ &, $91(1,0)$ \\
\hline Toinen aste, kesken & $2,04(1,55)$ & $1,45(1,44)$ \\
\hline Lyhyt ammattikoulutus & $1,63(1,28)$ & $1,04(1,05)$ \\
\hline Ammattikoulutus & $2,08(1,49)$ & $1,22(1,13)$ \\
\hline Ammattikorkea & $2,37(1,42)$ & $1,62(1,24)$ \\
\hline Yliopistotutkinto & $2,85(1,41)$ & $1,94(1,28)$ \\
\hline $\mathrm{Eta}^{2}$ &, $098^{* * *}$ & $.079 * * *$ \\
\hline \multicolumn{3}{|l|}{ Tietämys } \\
\hline 0 oikein & $.79(1,04)$ & $.63(1,05)$ \\
\hline 1 oikein & $1,1(1,17)$ & $.94(1,1)$ \\
\hline 2 oikein & $1,66(1,27)$ & $1,25(1,14)$ \\
\hline 3 oikein & $2,0(1,42)$ & $1,16(1,13)$ \\
\hline 4 oikein & $2,24(1,47)$ & $1,41(1,21)$ \\
\hline 5 oikein & $2,61(1,51)$ & $1,64(1,32)$ \\
\hline $\mathrm{Eta}^{2}$ &, $095^{* * *}$ & $.036 * * *$ \\
\hline \multicolumn{3}{|l|}{ |käryhmä } \\
\hline $18-30$ & $1,53(1,36)$ & $1,39(1,28)$ \\
\hline $31-45$ & $2,13(1,51)$ & $1,59(1,19)$ \\
\hline $46-60$ & $2,14(1,44)$ & $1,29(1,14)$ \\
\hline $61-$ & $2,06(1,45)$ & $.98(1,12)$ \\
\hline $\mathrm{Eta}^{2}$ & $.027^{* * *}$ &, $038^{* * *}$ \\
\hline \multicolumn{3}{|l|}{ Tulotaso } \\
\hline$<20000 €$ & $1,69(1,35)$ & $1,17(1,24)$ \\
\hline $20001-40000 €$ & $1,94(1,44)$ & $1,18(1,16)$ \\
\hline $40001-60000 €$ & $2,2(1,54)$ & $1,49(1,21)$ \\
\hline$>60000 €$ & $2,42(1,51)$ & $1,61(1,19)$ \\
\hline $\mathrm{Eta}^{2}$ &, $033^{* * *}$ & $.023 * * *$ \\
\hline \multicolumn{3}{|l|}{ Poliittinen kiinnostus } \\
\hline Ei lainkaan (kiinnostunut) & $.70(, 98)$ & $.73(, 95)$ \\
\hline Vain vähän & $1,34(1,16)$ & $1,32(1,02)$ \\
\hline Jonkin verran & $2,08(1,28)$ & $1,34(1,17)$ \\
\hline Erittäin & $3,09(1,55)$ & $1,68(1,39)$ \\
\hline $\mathrm{Eta}^{2}$ & $.228^{* * *}$ & $.053^{* * *}$ \\
\hline \multicolumn{3}{|l|}{ Poliittinen sijainti } \\
\hline Vasemmalla & $2,37(1,46)$ & $1,64(1,38)$ \\
\hline Keskellä & $1,74(1,36)$ & $1,27(1,18)$ \\
\hline Oikealla & $2,09(1,47)$ & $1,13(1,08)$ \\
\hline $\mathrm{Eta}^{2}$ & $.026^{* * *}$ &, $031^{* * *}$ \\
\hline \multicolumn{3}{|l|}{ Luottamus eduskuntaan } \\
\hline Vähäinen & $1,56(1,29)$ & $1,49(1,40)$ \\
\hline Keskinkertainen & $1,85(1,42)$ & $1,32(1,19)$ \\
\hline Korkea & $2,18(1,48)$ & $1,23(1,16)$ \\
\hline $\mathrm{Eta}^{2}$ &, $021^{* * *}$ & .004 \\
\hline Kaikki & $\begin{array}{r}1,98(1,46) \\
n=1290\end{array}$ & $\begin{array}{r}1,28(1,2) \\
n=1311\end{array}$ \\
\hline
\end{tabular}

Taulukko 2. Poliittinen osallistuminen eri vastaajaryhmissä2

pään opiskelleet. Luvut ovat hyvin samantyyppisiä ei-perinteisten osallistumistapojen kohdalla. Myös Etan neliöt ovat suuria, vaikka koulutustaso selittääkin enemmän konventionaalisen kuin epäkonventionaalisen poliittisen toiminnan aktiivisuutta. Koulutus on kuitenkin tärkein yksittäinen ei-perinteisen osallistumisen selittäjä. Poliittiset tietävimmät ovat myös poliittisesti aktiivisimpia. Tietotason ääripäiden kahden yksikön ero keskiarvoissa konventionaalisia osallistumismuotoja tarkasteltaessa on huomattava.

Ikä lisää poliittista aktiivisuutta sen perinteisissä muodoissa, mutta laskee aktiivisuutta ei-perinteisissä muodoissa. Varttuneempi väki näyttäisi osallistuvan nuoria innokkaammin perinteisin keinoin kun taas ei-perinteiset vaikuttamisen tavat ovat nuorten suosimia. Sama trendi on havaittavissa, kun tarkastellaan vastausten jakaantumista sen mukaan, kuinka hyvin kyselyyn osallistuneet luottavat eduskuntaan. Korkea luottamus lisää osallistumisaktiivisuutta konventionaalisten osallistumistapojen kohdalla, mutta näyttäisi hieman laskevan intoa turvautua epäkonventionaalisiin keinoihin. Jälkimmäisestä luottamus eduskuntaan kuitenkin selittää niin vähän, ettei riippuvuus ole tilastollisesti merkitsevä.

Edellä tarkasteltiin poliittista aktiivisuutta eri vastaajaryhmissä. Ilman monimuuttujaregressiota ei kuitenkaan ole mahdollista selvittää, minkä suuruinen vaikutus kullakin tekijällä on poliittiseen osallistumisaktiivisuuteen kun muiden tekijöiden vaikutus on huomioitu. Taulukoissa $\mathbf{3}$ ja $\mathbf{4}$ tarkastellaan perinteisen ja ei-perinteisen osallistumisen selittäjiä kolmella eri mallilla ordinaaliregression avulla. Ensimmäisessä mallissa selittäjänä on vain poliittinen tietämys, jonka vaikutus osallistumiselle on analyysin keskeisin kiinnostuksen kohde. Mallissa II mukana ovat kaikki selittävät muuttujat. Viimeisessä mallissa on raportoitu taaksepäin askeltavan regressioanalyysin tulokset. Siihen on päädytty poistamalla mallista tilastollisesti vähiten merkitseviä selittäjiä yksi kerrallaan, kunnes jäljellä on vain tilastollisesti merkitseviä 
muuttujia. Näillä kolmella mallilla pyritään selvittämään yhtäältä erityisesti tietämyksen merkitystä, toisaalta yleisesti muiden yleisimmin käytettyjen ja osallistumisen selittämisen kannalta mielekkäiden muuttujien vaikutusta.

Ordinaaliregressioista on raportoitu kunkin selittävän muuttujan estimaatti sekä Waldin testisuure. Estimaatti on kerroin, joka osoittaa selitettävän muuttujan oletettavan muutoksen, kun selittävän muuttujan arvo nousee yhdellä. Tärkeää on huomata, että kerroin on logaritminen, eikä näin ollen suoraviivaisesti arvioitavissa. Analyysin tuloksilla kyetäänkin selvittämään vaikutuksen suunta ja eri muuttujien vaikutusten väliset erot, koska kaikki muuttujat on skaalattu arvojen 0 ja 1 välille. Muuttujien vaikutuseroja voidaan arvioida myös Waldin testisuureen avulla. Tämä testi kertoo regression tilastollisesta merkitsevyydestä; mitä suuremman (ja tilastollisesti merkitsevän) arvon Wald saa, sitä suurempi on kyseisen muuttujan merkitys. Alimmilla riveillä on ilmoitettu mallin sopivuus (-2Log likelihood) sekä Nagelkerken näennäisselitysaste.

Tietämyksellä on vahvasti perinteisen poliittisen osallistumisen aktiivisuutta nostava vaikutus, mutta sen merkitys heikkenee selvästi, kun analyysiin lisätään muita muuttujia. Mallissa II suurimmat vaikutukset konventionaaliseen poliittiseen osallistumiseen ovat kiinnostuksella sekä koulutuksella. Niiden saamat estimaatit sekä Waldin testisuureen arvot ovat huomattavasti muita selittäviä tekijöitä suuremmat. Vaikutus on lisäksi positiivista eli kiinnostuksen lisääntyessä ja koulutustason noustessa poliittinen aktiivisuus kasvaa. Tämä havainto ei muutu vaikka siirryttäisiin tarkastelemaan mallia III, josta
Taulukko 3.

Perinteisen

osallistumisen

selittäjät,

ordinaaliregressio.

\section{Taulukko 4.}

Ei-perinteisen osallistumisen selittäjät, ordinaaliregressio.

\begin{tabular}{|c|c|c|c|c|c|c|}
\hline & \multicolumn{2}{|c|}{ Malli I } & \multicolumn{2}{|c|}{ Malli II } & \multicolumn{2}{|c|}{ Malli III } \\
\hline & $\begin{array}{l}\text { Estimaatti } \\
\text { (SE) }\end{array}$ & Wald & $\begin{array}{c}\text { Estimaatti } \\
\text { (SE) }\end{array}$ & Wald & $\begin{array}{c}\text { Estimaatti } \\
\text { (SE) }\end{array}$ & Wald \\
\hline Tietämys & $2,33(, 204)$ & $129,88^{* * *}$ & $.64(, 255)$ & $6,33^{*}$ & .760 & $10,53^{* *}$ \\
\hline Koulutus & & & $1,45(, 208)$ & $48,45^{* * *}$ & 1,40 & $56,66^{* * *}$ \\
\hline Sukupuoli & & & $.25(.113)$ & $4,88^{*}$ & & \\
\hline Tulotaso & & & $.29(, 171)$ & 2,81 & & \\
\hline Ikä & & & $.13(.316)$ & .16 & & \\
\hline Kiinnostus & & & $2,95(, 239)$ & $152,16^{* * *}$ & 2,89 & $170,99 * * *$ \\
\hline Poliittinen sijainti & & &.,$- 10(.027)$ & $13,33^{* * *}$ &,- 08 & $11,70^{* *}$ \\
\hline Luottamus eduskuntaan & & & $.58(.301)$ & 3,70 & & \\
\hline $\begin{array}{l}-2 \text { Log likelihood } \\
\text { Nagelkerke }\end{array}$ & \multicolumn{2}{|c|}{$\begin{array}{c}176,58^{* * *} \\
.101\end{array}$} & \multicolumn{2}{|c|}{$\begin{array}{c}3285,06^{* * *} \\
.295\end{array}$} & \multicolumn{2}{|c|}{$\begin{array}{c}2688,33^{* * *} \\
.270\end{array}$} \\
\hline
\end{tabular}

\begin{tabular}{|c|c|c|c|c|c|c|}
\hline & \multicolumn{2}{|c|}{ Malli I } & \multicolumn{2}{|c|}{ Malli II } & \multicolumn{2}{|c|}{ Malli III } \\
\hline & $\begin{array}{l}\text { Kerroin } \\
\text { (SE) }\end{array}$ & Wald & $\begin{array}{l}\text { Kerroin } \\
\text { (SE) }\end{array}$ & Wald & $\begin{array}{l}\text { Kerroin } \\
\text { (SE) }\end{array}$ & Wald \\
\hline Tietämys & $1,258(, 197)$ & $40,656 * * *$ &, 463 & 3,305 & & \\
\hline Koulutus & & &, 987 & $22,614^{* * *}$ & 1,059 & $26,811^{* * *}$ \\
\hline Sukupuoli & & & .620 & $29,220 * * *$ & .607 & $28,212^{* * *}$ \\
\hline Tulotaso & & & .524 & $9,226 * *$ & .592 & $12,397^{* * *}$ \\
\hline Ikä & & & $-2,424$ & $53,397^{* * *}$ & $-2,397$ & $52,428 * * *$ \\
\hline Kiinnostus & & & 1,204 & $27,774^{* * *}$ & 1,315 & $35,688^{* * *}$ \\
\hline Poliittinen sijainti & & &,- 143 & $26,994^{* * *}$ &,- 146 & $28,382^{* * *}$ \\
\hline Luottamus eduskuntaan & & & -.924 & $9,245^{* *}$ &,- 918 & $9,118^{* *}$ \\
\hline $\begin{array}{l}-2 \text { Log likelihood } \\
\text { Nagelkerke }\end{array}$ & \multicolumn{2}{|c|}{$\begin{array}{c}173,548^{* * *} \\
.032\end{array}$} & \multicolumn{2}{|c|}{$\begin{array}{c}2989,288^{* * *} \\
.205\end{array}$} & \multicolumn{2}{|c|}{$\begin{array}{c}2990,450 * * * \\
.203\end{array}$} \\
\hline
\end{tabular}


epävarman vaikutuksen omaavat muuttujat on yksi kerrallaan poistettu. Samalla on merkittävää huomata, että selittävien tekijöiden karsiminen puoleen ei olennaisesti laske mallin selitysastetta: mallissa II se on 29,5 prosenttia ja mallissa III 27 prosenttia. Vastaajan sijoittuminen vasemmisto-oikeisto akselilla on mallin mukaan tilastollisesti merkitsevä tekijä ja vaikutuksen suunta on yksiselitteinen: itsensä sijoittaminen poliittisessa kentässä vasemmalle näyttäisi hieman nostavan perinteisen osallistumisen aktiivisuutta.

Taulukossa 4 on esitetty vastaava ordinaalinen regressio ei-perinteisen osallistumisen suhteen. Ero perinteisten osallistumismuotojen esiintymiseen on varsin selvä. Ensinnäkin malliin valittujen muuttujien yhteinen selitysaste laskee noin 20 prosenttiin, mutta on kuitenkin vielä varsin korkea. Selittävät muuttujat selittävät toisin sanoen enemmän perinteisen kuin eiperinteisen osallistumisen vaihtelusta. Huomattavaa on, ettei poliittinen tietämys päätynyt tilastollisesti merkitsevänä muuttujana malliin III. Toisin sanoen tietämyksellä ei näyttäisi olevan muihin muuttujiin verrattuna suurta vaikutusta epäkonventionaaliseen poliittiseen osallistumisen selittäjänä.

Toisaalta on huomattava, että tietämys putosi pois mallista III vain ns. kalkkiviivoilla, sillä muuttuja olisi ollut merkitsevä 0,1 merkitsevyystasolla. Mallista I kuitenkin nähdään, että tietämyksen vaikutus on odotetun positiivinen myös ei-perinteisen osallistumisen osalta, vaikka sen vaikutus siis marginaalinen onkin. Lopuilla seitsemällä selittävällä muuttujalla on tilastollisesti merkitsevä Waldin testisuureen arvo ja vaihtelevan korkea estimaattikerroin. Mallissa III on kiinnitettävä huomio kolmeen muuttujaan, joiden kerroin on negatiivinen. Epäkonventionaalisen osallistumisen aktiivisuus siis laskee iän kertyessä sekä luottamuksen eduskuntaa kohtaan parantuessa. Lisäksi näyttää siltä, että poliittinen vasemmistolaisuus lisäisi hieman myös ei-perinteistä aktiivisuutta. Iän merkitys on mallin mukaan poikkeuksellisen suuri. Muuttujan estimaatti on huomattava -2.397 ja Waldin testin lukema 52,428. Kiinnostus ja koulutus olivat jälleen merkitseviä ja vahvasti selittäviä muuttujia, mutta yllättävää on myös sukupuolen rooli. Naiset ovat ei-perinteisten osallistumismuotojen osalta miehiä aktiivisempia.

\section{KUMULOITUVA OSALLISTUMINEN}

Edellä esitettyjen mallien ero perinteisen ja ei-perinteisen osallistumisen välillä on tähän mennessä ollut analyysitekninen. Todellisuudessa osallistuminen usein kumuloituu: kansalaiset, jotka osallistuvat yhdellä tavalla, osallistuvat myös toisella. Taulukossa 5 kyselyyn vastanneet on jaettu luokkiin poliittisen aktiivisuuden perusteella. Ensimmäinen ja suurin luokka (62 prosenttia), joka toimii myös jäljempänä regression vertailuryhmänä, on ns. tavanomaisten osallistujien ryhmä. Heitä ovat vastaajat, jotka osallistuvat politiikkaan korkeintaan kahdella artikkelin alussa esitellyllä tavalla. Toisessa ryhmässä ovat yli kahdella perinteisellä tavalla osallistuvat, mutta joiden aktiivisuus on tätä vähäisempää ei-perinteisillä muodoilla. Nämä konventionaaliaktiivit muodostivat 22,3 prosenttia kyselyyn vastanneista. Epäkonventionaaliaktiivit taas suosivat ei-perinteisiä poliittisen vaikuttamisen keinoja. He osallistuivat yli kahdella epäkonventionaalisella tavalla, mutta korkeintaan kahdella konventionaalisella vaikuttamistavalla. Neljäntenä ovat superaktiivit, jotka osallistuivat yli kahdella molemman poliittisen osallistumisen luokittelun keinolla.

Taulukossa 6 selitetään yksilön todennäköisyyttä kuulua johonkin näistä ryhmistä. Waldin testisuure kertoo muuttujan tilastollisen merkitsevyyden. $\operatorname{Exp}(B)$ on ryhmäkuuluvuutta ennustava riskikerroin. Esimerkiksi riskikerroin 2,983, joka kuvaa tietämyksen vaikutusta todennäköisyyteen kuulua superaktiiveihin suhteessa tavanomaisiin osallistujiin osoittaa, että tietämyksen kasvaessa yhdellä yksiköllä, kasvaa yksilön mahdollisuus kuulua superaktiiveihin 2,983-kertaiseksi tavanomaisen aktiivisuuden ryhmään verrattuna. Jos kerroin on alle yhden, kuten on jokaisen ryhmän kohdalla poliittisen sijainnin tapauksessa, on todennäköisempää kuulua vertailtavaan ryhmään eli tavanomaisiin osallistujiin. Näin ollen poliittisesti oikealla oleminen lisää riskiä kuulua vähemmän poliittisesti aktiiviseen vastaajien valtaosaan.

Kun selitetään yksilön kuulumista superaktiivien luokkaan, huomattavimmaksi tekijäksi muodostuu kiinnostus. Kiinnostuksen kasvaessa riskikerroin kuulua superaktiiveihin ennemmin kuin tavanomai- 
Taulukko 5. Osallistumistyypit.

\begin{tabular}{|c|c|c|c|}
\hline \multirow[b]{4}{*}{ Epäkonventionaalinen osallistuminen } & & \multicolumn{2}{|c|}{ Konventionaalinen osallistuminen } \\
\hline & \multirow{3}{*}{$\begin{array}{l}\text { Aktiivinen } \\
\text { Passiivinen }\end{array}$} & Aktiivinen & Passiivinen \\
\hline & & Superaktiivit 9,5\% & Epäkonventionaaliaktiivit 6,1% \\
\hline & & Konventionaaliaktiivit 22,3\% & Tavanomaiset osallistujat $62 \%$ \\
\hline
\end{tabular}

\section{Taulukko 6}

Osallistumistyyppien

selittäjät,

regressio $(n=1310)$ multinominaalinen

\begin{tabular}{|c|c|c|c|c|c|c|}
\hline & \multicolumn{2}{|c|}{$\begin{array}{l}\text { Superaktiivit vs. } \\
\text { tavanomaiset }\end{array}$} & \multicolumn{2}{|c|}{$\begin{array}{c}\text { Konventionaalit vs. } \\
\text { tavanomaiset }\end{array}$} & \multicolumn{2}{|c|}{$\begin{array}{l}\text { Epäkonventionaalit } \\
\text { vs. tavanomaiset }\end{array}$} \\
\hline & Wald & $\operatorname{Exp}(B)$ & Wald & $\operatorname{Exp}(B)$ & Wald & $\operatorname{Exp}(B)$ \\
\hline Vakio & $48.909 * * *$ & & $74.480^{* * *}$ & & $16.456^{* * *}$ & \\
\hline Tietämys & $1.093^{*}$ & 2.983 & .530 & 1.314 & .568 & 1.589 \\
\hline Koulutus & $2.313^{*}$ & 10.102 & $25.142^{* * *}$ & 4.551 & $8.721^{* *}$ & 4.254 \\
\hline Sukupuoli & $15.791^{* * *}$ & 2.571 & .004 & 1.011 & $10.368^{* *}$ & 2.401 \\
\hline Tulotaso & 3.025 & 1.794 & $4.871^{*}$ & 1.724 & $6.196^{*}$ & 2.603 \\
\hline Ikä & $9.583^{* *}$ & .095 & 1.155 & 1.643 & 1.371 & .242 \\
\hline Kiinnostus & $48.594^{* * *}$ & 46.603 & $43.168^{* * *}$ & 10.680 & $9.130 * *$ & 5.262 \\
\hline Poliittinen sijainti & $12.705^{* * *}$ & .822 & 1.562 & .952 & $6.459 *$ & .849 \\
\hline Luottamus eduskuntaan & $5.732^{*}$ & .236 & 3.246 & 2.415 & $15.3779 * * *$ & .080 \\
\hline $\begin{array}{l}\text {-2Log likelihood } \\
\text { Nagelkerke }\end{array}$ & $\begin{array}{r}1929,35^{* * *} \\
. .304\end{array}$ & & & & & \\
\hline
\end{tabular}

siin osallistujiin on 46,603. Myös lisääntynyt koulutus ja kasvanut tietämys lisäävät mahdollisuutta kuulua superaktiiveihin. Naiset ovat todennäköisempiä superaktiiveja kuin miehet. Ihmisen vanhetessa todennäköisyys kuulua superaktiiveihin pienenee.

Kiinnostus ja koulutus ovat tärkeitä myös verrattaessa konventionaaliaktiiveja tavanomaisiin. Muista muuttujista vain tulotaso on tilastollisesti merkitsevä. Ryhmäkuuluvuuden todennäköisyyttä epäkonventionaalien osalta lisää korkea koulutus, naissukupuoli, korkea tulotaso ja kiinnostuneisuus. Kiinnostus ei ole kuitenkaan enää yhtä hallitsevassa asemassa kuin edellisissä vertailuissa. Luottamus eduskuntaan on negatiivisessa yhteydessä eli suurempi luotto eduskuntaan pienentää riskiä kuulua niihin, jotka osallistuvat aktiivisemmin ei-perinteisin kuin konventionaalisin keinoin.

Taulukon 6 lopussa on esitetty multinominaalisen regressiomallin uskottavuusaste, joka on tilastollisesti merkitsevä 1929,35. Nagelkerken arvo 0,304 taas kertoo siitä, että malli onnistuu selittämään peräti kolmekymmentä prosenttia poliittisten osallistumistyyppien ryhmäkuuluvuudesta.

\section{KESKUSTELU}

Edellä on tarkasteltu poliittisen tietämyksen yhteyttä perinteiseen ja ei- perinteiseen osallistumiseen sekä erikseen että osallistumisen kumuloituminen huomioon ottaen. Analyysien perusteella tehtiin seuraavia havaintoja:

- Korkea politiikkatietämys on yhteydessä korkeaan osallistumisaktiivisuuteen. Yhteys on vahvempi perinteisten kuin ei-perinteisten vaikuttamismuotojen kohdalla.

- Todennäköisyys kuulua poliittisesti erittäin aktiivisiin kansalaisiin kasvaa, kun tietämys politiikasta lisääntyy.

- Politiikkakiinnostus sekä korkea koulutustaso ovat tärkeimmät korkean perinteisen poliittisen osallistumisen selittäjät.

- Nuori ikä on tärkein epäkonventionaalisen osallistumisen vilkkautta. Myös heikko luottamus eduskuntaa kohtaan lisää ei-perinteisen osallistumistyypin todennäköisyyttä.

- Poliittisen osallistumisen selittäjänä tietämys jää poliittisen kiinnostuksen ja koulutustason varjoon. Suhde lähentelee kuitenkin analyyttisesti ja empii- 
risesti tautologiaa, joten huomion kiinnittäminen

koulutuksen merkitykseen on tässä yhteydessä perusteltua.

Havainto on mielenkiintoinen, koska Suomea on syystäkin pidetty pohjoismaisen hyvinvointiajattelun mukaisena, sosiaalisesti ja taloudellisesti tasa-arvoisena ja tasa-arvoistavana yhteiskuntana. Siksi voitaisiin ajatella, ettei koulutusta-

Mit solla olisi Suomessa näin vahvaa kansalaisia erottelevaa merkitystä yhteiskunnallisen osallistumisen KANNALTA ja kiinnittyneisyyden indiMERKITSEE, ETTÄ ENITEN POLIITTISESTI

OSALLISTUVAT KANSALAISET MYÖS TIETÄVÄT ENITEN POLITIIKASTA? kaattorina. Suomessa(kin) korkeasti koulutetut ovat kuitenkin poliittisen osallistumisen mittareilla tarkasteltuna selvästi kiinnittyneempiä yhteiskuntaan kuin alemman koulutustason kansalaiset.

Samalla aktiivisesti politiikkaan osallistuvat ihmiset ovat poliittisesti tietävämpiä kuin vähemmän osallistuvat tai kokonaan passiiviset. Tämä tilastollisesti vahva yhteys ei kuitenkaan kerro mitään kausaatiosta. Onkin täysin mahdotonta erotella selittäjää ja selitettävää toisistaan, jotta voitaisiin saada selville, kumpi on toisen perustana. Ymmärrys politiikan prosesseista sekä ajankohtaisen poliittisen tilanteen tuntemus kannustavat osallistumaan ja samalla aktiivinen yhteiskunnallinen vaikuttaminen lisää kansalaisen tietoja politiikasta.

Pippa Norrisin "hyveiden kehä" -ajatusta (Norris, 2000) mukaillen voidaan tuloksia tulkita eräänlaiseksi positiiviseksi kansalaisuuden kierteeksi, jossa osallisuus, osallistuminen ja tietämys nivoutuvat yhteen ja kasvattavat toinen toisiaan. Kiinnostavaksi ja kenties tärkeimmäksi tulevaisuuden tutkimuskysymykseksi muodostuu täten pääsy hyveiden kehälle: kenen kohdalla positiivinen kierre käynnistyy, kenen ei?

Tuloksia on aiheellista pohtia myös normatiiviselta kantilta. Mitä yhteiskunnan kannalta merkitsee, että eniten poliittisesti osallistuvat kansalaiset myös tietävät eniten politiikasta? Vallankäytön oikeutuksen kannalta tuskin on suurta merkitystä sillä, minkälaisen politiikkatietämyksen pohjalta kansalaiset äänestävät; kansanedustajan mandaatti olisi yhtä pitävä, vaikka tutkimuksen tulos olisikin päinvastainen.

Ei ole myöskään selvää, että politiikasta tietäminen vaikuttaisi ratkaisevasti kansalaisen kykyyn tehdä oikeita valintoja, koska politiikassa ei ole pelkästään kyse vaihtoehtojen yleisestä, objektiivisesta oikeellisuudesta, vaan subjektiivisesti koetusta hyvyydestä. Aiempi (amerikkalainen) tutkimus on kuitenkin osoittanut, että tietämys nostaa kansalaisen todennäköisyyttä äänestää vaihtoehtoa, joka vastaa parhaiten tämän omia preferenssejä (Lau \& Redlawsk, 1997).

Tietämys ei siis ole äänestämisen kannalta yhdentekevää. Jos demokratia kehittyisi osallistuvampaan suuntaan ja neuvoa-antavien kansanäänestysten määrä lisääntyisi, olisi prosessin kannalta tähdellistä, että kansalaisten valinnat perustuisivat tietoon. Neuvon kysyminen täysin satunnaisesti käyttäytyviltä kansalaisilta tarkoittaisi arvontaan perustuvaa valintaa vaihtoehtojen kesken.

Tiedon merkitys korostuu, kun kansalaisosallistuminen nostetaan edustuksellisen demokratian toiminnan keskiöön. Bernand Berelsonin kuvailema ihannekansalainen - ei alamainen - on tässä ympäristössä omimmillaan. Siksi tuloksessa, jonka mukaan eniten politiikkatietämystä omaavat kansalaiset myös osallistuvat yhteiskunnallisiin asioihin eniten, ei ole demokratiateorian näkökulmasta mitään odottamatonta. Poliittinen toiminta perustuu vapaaehtoisuuteen ja tällöin osallistujajoukko rakentuu luonnollisesti. Normatiivisesti ajatellen tämänkaltainen osallistujajoukon muodostuminen on ainoastaan toivottavaa.

Ihannetilanne voisi olla sellainen, jossa kaikki tietotasosta riippumatta osallistuisivat yhtä lailla. Suomessa ja muualla onkin kiinnitetty laajalti huomiota poliittisen osallistumisaktiivisuuden, etenkin äänestysvilkkauden, nostamiseen. Optimistisen katsantokannan mukaan äänestysaktiivisuuden nostamiseen tähtäävät toimenpiteet voisivat aikaansaada edellä esitetyn kaltaisen positiivisen kierteen, jossa kansalaisten poliittinen aktivoituminen johtaisi myös samanaikaiseen politiikkatietämyksen kasvuun. 
Aiempi tutkimus kuitenkin antaa syytä uskoa pikemminkin koulutuksen voimaan politiikkatietämyksen - ja mahdollisesti sitä kautta myös poliittisen aktiivisuuden - kasvattajana. Erityisen ratkaiseva vaihe näyttäisi olevan peruskoulutuksen jälkeinen, toisen asteen koulutus. Se osuu myös ajallisesti vaiheeseen, jolloin yhteiskunnallinen identiteetti ja etenkin poliittinen kiinnostus muotoutuvat (ks. esim. Shani 2009; Prior 2010). Lukiovaiheen yhteiskunnallisen opetuksen vaikutus politiikkatietämykselle on dokumentoitu (Denver \& Hands 1990), ja myös Suomessa lukiolaisten ja ammattikoulutettavien välillä on havaittu selvä ero politiikkatietämyksessä (Elo 2009). Toisen asteen koulutuksen merkitystä Suomessa tukee myös havainto, jonka mukaan yliopistokouluttautumisessa alan valinta ei enää vaikuta politiikkatietämykseen: yhteiskunnallisen alan yliopistokoulutuksen saaneet eivät tiedä politiikasta muita yliopistokoulutettuja enemmän (Rapeli 2010, 52).

Suomessa koulutusjärjestelmän tarjoama yhteiskuntaopin opetus päättyy toisen asteen jälkeen, alan yliopisto-opintoja lukuun ottamatta. Työmarkkinoiden tarpeeseen luodussa aikuiskoulutusjärjestelmässä ei ole kansalaisosallistumista tukevaa yhteiskunnallisten aineiden opetustarjontaa. Toisen asteen jälkeen koulutusjärjestelmä ei tarjoa Suomessa politiikkatietämyksen kehittymiselle mahdollisuuksia muille kuin yhteiskuntatieteellisten tiedekuntien opiskelijoille, ja eriytyminen, kuten todettua, tapahtuu jo heti peruskoulun jälkeen.
Saatujen tulosten tulkinnassa on otettava huomioon, että käytetty tietämyksen mittari liittyi perinteisiin osallistumismuotoihin, jolloin ei-perinteisiin osallistumismuotoihin liittyvä tietämys jäi mittauksen ulkopuolelle. Tämä saattaa osaltaan selittää, miksi tietämys näiden tulosten perusteella oli vahvemmassa yhteydessä perinteiseen kuin ei-perinteiseen osallistumiseen. On mahdollista, että mikäli vastaajilta olisi kysytty vaikkapa mielenosoituskäytäntöihin tai poliittiseen kulutuskäyttäytymiseen liittyviä tietokysymyksiä, olisi tietämyksen ja osallistumisen suhde näyttäytynyt erilaisena. Tässäkin tapauksessa olemassa olevien aineistojen aiheuttamat puutteet on mahdollista korjata vain tulevaisuuden aineistoja parantamalla.

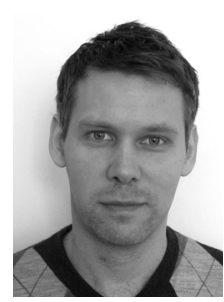

Lauri Rapeli

VTT, yliopisto-opettaja

Politiikan tutkimuksen laitos, Turun yliopisto

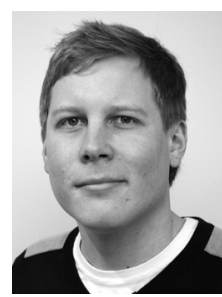

Mikko Leino

VTM, jatko-opiskelija

Politiikan tutkimuksen laitos, Turun yliopisto 


\section{LÄHTEET}

Bengtsson, Åsa \& Kimmo Grönlund (2005). Muu poliittinen osallistuminen. Teoksessa Paloheimo, Heikki (toim.), Vaalit ja demokratia Suomessa. WSOY, Helsinki, 147-168.

Berelson, Bernard (1952). Democratic Theory and Public Opinion. Public Opinion Quarterly, 16(3). 313-330.

Berelson, Bernard R., Lazarsfeld, Paul F. \& McPhee, William N. (1954). Voting: A Study of Opinion Formation in a Presidential Campaign. The University of Chicago Press, Chicago, Ill.

Denver, David \& Gordon Hands (1990). Does Studying Politics Make a Difference? The Political Knowledge, Attitudes and Perceptions of School Students. British Journal of Political Science, 20(2), 263-279.

Elo, Kimmo (2009). Kiinnostuksesta se kaikki lähtee... - Havaintoja äänestysikää lähestyvien nuorten politiikkatietämyksestä. Kasvatus, 40(1), 36-48.

Grönlund, Kimmo \& Maija Setälä (2007). Political trust, satisfaction and voter turnout. Comparative European Politics 5(4), 400-422.

Lau, Richard R. \& Redlawsk, David P. (1997). Voting Correctly. American Political Science Review, 91(3), 585-598.

Marsh, Alan \& Max Kaase (1979), Measuring Political Action. Teoksessa Barnes, Samuel H. Max Kaase (toim.), Political Action: Mass Participation in Five Western Democracies. Sage, Beverly Hills, 58-97.

Milbrath, Lester. W. (1965). Political participation. Chicago, IL: Rand McNally.

Milner, Henry (2002). Civic Literacy: How Informed Citizens Make Democracy Work. University Press of New England, Hanover and London.

Neuman, Russell W. (1986). The Paradox of Mass Politics: Knowledge and Opinion in the American Electorate. Harvard University Press, Cambridge, MA.

Norris, Pippa (2000). A Virtuous Circle. Political Communication in Postindustrial Societies. Cambridge University Press, Cambridge.

Prior, Markus (2010). You've Either Got It or You Don't? The Stability of Political Interest over the Life Cycle. The Journal of Politics, 72(3), 747-766.

Rapeli, Lauri (2010). Tietääkö kansa? - Kansalaisten politiikkatietämys teoreettisessa ja empiirisessä tarkastelussa. Annales Universitatis Turkuensis C 296. Turun yliopisto, väitöskirja.

Shani, Danielle (2009). On the Origins of Political Interest. PhD Dissertation, Princeton University: Princeton, NJ.
Topf, Richard (1995). Electoral Participation. Teoksessa Klingemann, Hans-Dieter \& Dieter Fuchs (toim.), Citizens and the State. Beliefs in Government. Vol. 1. Oxford: Oxford University Press, 27-51.

Warren, Mark E. (1999). Conclusion. Teoksessa Warren, Mark E. (toim.): Democracy and Trust, ss. 346-360. Cambridge: Cambridge University Press.

Wass, Hanna (2008). Generations and turnout. The generational effect in electoral participation in Finland. Acta Politica 35. Helsinki: Helsinki University Print.

Weissberg, Robert (1974). Political learning, political choice, and democratic citizenship. Prentice-Hall, Englewood-Cliffs, NJ.

\section{VIITTEET}

1 Tukeudumme poliittisen osallistumisen ja normatiivisen demokratiateorian osalta tutkimuksessamme amerikkalaiseen tutkimusperinteeseen, koska sen kautta ilmentyvät parhaiten tutkimusalan keskeiset lähestymistavat. Tämä valinta rajaa tutkimuksen ulkopuolelle uuden, kansalaislähtöisen näkökulman edustukselliseen demokratiaan ja kansalaisuuteen, jossa perinteisen ja ei-perinteisen osallistumisen raja on erilainen, ehkä jopa merkityksetön.

2 Kielellisen monipuolisuuden nimissä käytämme jatkossa myös termejä konventionaalinen/ epäkonventionaalinen.

3 Tutkimuksen teki Taloustutkimus oy Vaalitutkimuskonsortion toimeksiannosta. Käyntihaastattelut tehtiin 18.04-28.05.2011. Perusjoukosta, 2011 eduskuntavaaleissa äänioikeutetut Suomessa asuvat henkilöt (pl. Ahvenanmaal, otettiin otos kiintiöpoiminnalla iän, sukupuolen ja läänijakauman mukaan.

4 Kysytty erillisellä kysymyksellä, ks.liite.

5 Ikä, poliittinen sijainti ja luottamus eduskuntaan ovat jatkoanalyyseissä ns. jatkuvia muuttujia, eivätkä tämän taulukon mukaisia luokiteltuja muuttujia. Nämä muuttujat luokiteltiin tätä taulukkoa varten, jotta niitä voidaan vertailla muihin muuttujiin. 


\section{Selitettävät muuttujat}

Seuraavassa on joukko erilaisia yhteiskunnallisen osallistumisen muotoja. Mitä näistä olette tehnyt viimeksi kuluneiden neljän vuoden aikana, tai jos tuntisitte asian tärkeäksi mitä saattaisitte tehdä. 1. Olen tehnyt viimeksi kuluneiden neljän vuoden aikana; 2 . En ole tehnyt, mutta saattaisin tehdä; 3. En tekisi missään tapauksessa; 4. En osaa sanoa. Koodaus: Olen tehnyt viimeksi kuluneiden neljän vuoden aikana $=1$, muutoin $=0$.

Perinteinen poliittinen osallistuminen = Kirjoittaa yleisönosastoon; Ottaa yhteyttä poliittisiin päätöksentekijöihin jossakin tärkeässä asiassa; Kirjoittaa nimenne vetoomuksiin tai nimenkeräyksiin; Osallistua poliittisen puolueen toimintaan; Osallistua muun järjestön toimintaan.

Lisäksi erillinen kysymys äänestämisestä 2011 eduskuntavaaleissa Jätittekö Te näissä eduskuntavaaleissa äänestämättä? 1. Jätin tällä kertaa äänestämättä; 2. Kävin äänestämässä ennakkoon; 3. Kävin äänestämässä varsinaisena vaalipäivänä; 4 . Ei halua sanoa; 5. Ei osaa sanoa; 6. Ei äänioikeutta. Koodaus: 2. Kävin äänestämässä ennakkoon tai 3. Kävin äänestämässä varsinaisena vaalipäivänä = 1, muutoin 0. Ei äänioikeutta -vastaukset jätettiin analyysin ulkopuolelle.

Jokaisesta "Olen tehnyt viimeksi kuluneiden neljän vuoden aikana" -vastauksesta annettiin 1 piste + 1 piste, jos äänesti 2011 eduskuntavaleissa. Yhteenlaskettuna tuloksena summamuuttuja skaalalla 0-6.

Ei-perinteinen osallistuminen = Tehdä omia ostopäätöksiäni siten, että voisin kulutustavoillani edistää luonnon suojelua; Tehdä omia ostopäätöksiäni siten, että voisin kuluttajana vaikuttaa yhteiskunnallisiin tai poliittisiin asioihin; Osallistua boikottiin, maksu- tai ostolakkoon; Osallistua rauhanomaisiin mielenosoituksiin; Osoittaa kansalaistottelemattomuutta osallistumalla väkivallattomaan laittomaan toimintaan; Osallistua sellaisiin mielenosoituksiin, joissa aiemmin on ilmennyt väkivaltaa; Käyttää väkivaltaa poliittisten päämäärien saavuttamiseksi.

Sama koodaus kuin yllä, yhteenlaskettu summamuuttuja skaalalla 0-7.

\section{Selittävät muuttujat}

Tietämys, ks. "AINEISTO JA MUUTTUJAT"

Sukupuoli: 0 = nainen; 1 = mies.

Koulutus: 0 = Ei muodollista ammattikoulutusta; ,20 = 2. asteen koulutus kesken; ,40 = lyhyt ammattikoulutus; ,60 = ammattikoulutus; , 80 = ammattikorkeakoulutus; 1 $=$ yliopistokoulutus.

Ikä: (Ikä vuosina/100)². Iän neliötä käytetään, koska iän ja poliittisen osallistumisen suhteen on havaittu olevan kurvilineaarinen (Milbrath 1965, 134-135; ks. myös Wass 2008, 16).

Tulotaso: Talouden vuositulot, $0=$ alle $20000 € ; 20001-$ $40000 €=, 33 ; 40001-60000 €=, 66$; yli $60000 €=1$.

Poliittinen kiinnostus: Kuinka kiinnostunut olette politiikasta? 0 = Ei lainkaan (kiinnostunut); ,33 = Vain vähän; ,66 = Jonkin verran; 1 = Erittäin.

Poliittinen sijainti: Politiikassa puhutaan joskus vasemmistosta ja oikeistosta. Käytämme asteikkoa, jossa nolla tarkoittaa eniten vasemmalla ja kymmenen eniten oikealla. Mihin kohtaan sijoittaisitte itsenne tällä asteikolla? Vastaajan valitsema arvo/10.

Luottamus eduskuntaan: Missä määrin luotatte tai ette luota seuraaviin tahoihin? Arvioikaa kutakin tahoa asteikolla nollasta kymmeneen, missä nolla tarkoittaa "en luota ollenkaan" ja 10 "luotan täydellisesti". Eduskunta. Vastaajan valitsema arvo/10. 